\title{
Five to One: Rethinking the Doors and the Sixties Counterculture ${ }^{1}$
}

\section{CHRISTOPHER CRENSHAW}

"Five to One" is an evocative phrase. For listeners aware of the Doors song by the same title, it can bring to mind images of sex, fear, death, freedom, revolution, or simply drugs and alcohol. It can be a good-time anthem or a sobering indictment of the sixties. For listeners in the sixties, this double meaning was likely intentional. The song's lyrics are loaded with double- or triple-meanings. In the 1968 recording from the LP Waiting for the Sun, lead singer Jim Morrison's vocals are at times audibly slurred; but the song starts off strong. "Love my girl, she lookin' good," Morrison almost whispers into the microphone, establishing a sexual tone from the beginning before letting his listeners know that "no one here gets out alive." Joan Didion remarked on this sex/death duality in an essay in The White Album (1979). The Doors, she claimed, were "missionaries of apocalyptic sex." They "seemed unconvinced that love was brotherhood and the Kama Sutra" and "insisted that love was sex and sex was death and therein lay salvation." 2 Other double meanings in the song are equally illustrative. In the next stanza Morrison sings, "they got the guns, but we got the numbers." At face value, the lyric can be interpreted as an overt political message. The police may have "the guns," but the people "got the numbers." Organist Ray Manzarek, however, revealed another meaning of the song in a 1968 interview in Life magazine. "In California, a number is another name for a joint, a marijuana cigarette," he pointed out, adding drily, "[I] just thought you might want to know that." 3 Sex, death, politics, drugs. Many of the Doors' songs are as cryptic and suggestive as "Five to One."

"Five to One" is meaningful on another level, though. Discussions about music feature prominently in many historical accounts of the sixties counterculture. While they have acknowledged that the counterculture was complex and nuanced, historians continue to focus on San Francisco bands like the Grateful Dead, Jefferson Airplane, and Country Joe \& The Fish to describe the popular culture that issued from and reinforced it from 1967 to 1969. In his acclaimed 1996 book And the Crooked Places Made Straight historian David Chalmers provides an excellent example of this dominant interpretation. "Somewhere about the year 1967... the hippie culture turned into the counterculture," he explains. "San Francisco gave birth to it," and "life was psychedelia." San Francisco bands became the "model," in his view, of a "tribal-love rock musical" that became popular in that year. The Los Angeles-based Doors released their first and most successful album in 1967, though, and by the end of the "summer of love" it was number one on the national charts. By the end of the year, the Doors had two albums-The Doors and Strange Days—on the Billboard Top 10. For every Grateful Dead album a listener bought, at least five others bought an album by the Doors. For the rare listener who called in to a radio station to request a song by Country Joe \& The Fish, at least five called in to request "Light My Fire" or "Break on Through." These listeners were aware of the Doors' message, even if they often misinterpreted it. Many fans and

\footnotetext{
${ }^{1}$ The author wishes to thank Dr. Louise Newman at the University of Florida for her guidance on this project.

${ }^{2}$ Joan Didion, The White Album (New York: Pocket Books, 1979), 21.

${ }^{3}$ Fred Powledge, "Wicked Go The Doors," Life, April 12, 1968, 90.
} 
critics identified the band with a particular set of "psychedelic," even "revolutionary," countercultural credentials. "Five to One," then, illustrates both the webs of meaning in the individual songs of the Doors and the role that the band played in the popular counterculture.

Because popular music albums are, in most cases, mass-produced and marketed for profit by large corporations, they present a superficial paradox for historians who wish to interpret "authentic" cultural documents. Do record corporations produce and sell what the public really wants to hear, or do they shape the public's tastes to match their own economic needs? Cultural studies and media scholars have addressed this issue by defining two different "values" of cultural products. Record companies depend on the exchange, or economic, value of an album or single to stay in business, while consumers respond to the use, or "cultural," value of the album when they listen to it. "The music industry can control the first," cultural studies scholar John Storey explains, "but it is consumers who make the second."

The Doors crossed over the divide between corporation and consumer. While it was fashionable to scorn commercial success in San Francisco and other "underground" markets, the Doors and other bands in the Los Angeles scene kept a close eye on their appeal in the market. ${ }^{5}$ Elektra vice president Steve Harris recalls Morrison's concern with the band's success. "I would always say to the boys, 'Oh, the record jumped from this to this, and it's got a bullet," he remembers, "[and] they gave the facade, or at least Jim did, of I don't care." After going "a couple of days" without bringing up record sales, however, Morrison "cornered" Harris and asked, "Well, where did the record go? How much is it selling?" Robby Krieger shares a similar memory of Morrison: "Jim never thought we were big enough. He thought we should be at least as big as the Stones. It never happened fast enough for him." ${ }^{6}$ The band was happy to discuss sales with interviewers as well. In a 1967 promotional spot on SUNY Oswego college radio, for example, the band chatted about royalties, chart positions, touring, and fame with student interviewers. ${ }^{7}$ There was no apparent contradiction between fame, success, and social commentary for the Doors and many of their Los Angeles counterparts.

For historians, the use value of popular music has special significance. Popular songs and albums are freighted with "hidden histories," according to cultural scholar George Lipsitz. Because consumption is such an important part of daily life for so many people, Lipsitz argues that popular music products become "focal points" that allow consumers to express ideas and emotions that are not possible in other types of cultural products. ${ }^{8}$ This "uses and gratifications" approach to pop culture emphasizes the active role of consumers in the market. ${ }^{9}$ Because listeners used the music of the Doors and other late sixties bands to meet their own needs-and often to shape their identities- the commercial albums these bands produced are definitely "authentic" cultural documents.

The "uses and gratifications" of sixties music consumers necessitates a reassessment of the relationship between the music of the Doors and the counterculture. First, the individual Doors, Jim

\footnotetext{
${ }^{4}$ John Storey, Cultural Studies \& the Study of Popular Culture: Theories and Methods (Athens: University of Georgia Press, 1996), 97.

${ }^{5}$ Sarah Hill, "When Deep Soul Met the Love Crowd: Otis Redding: Monterey Pop Festival, June 17, 1967," in Performance and Popular Music: History, Place and Time, ed. Ian Inglis (Aldershot, Hants, England: Ashgate, 2006), 30.

${ }^{6}$ Jac Holzman and Gavan Daws, Follow the Music: The Life and High Times of Elektra Records in the Great Years of American Pop Culture (Santa Monica, Cal: FirstMedia Books, 1998), 174.

${ }^{7}$ The Doors, interviewed by SUNY Oswego broadcasters, The Lost Interview Tapes Featuring Jim Morrison, vol. 1, The Doors, Rhino/Bright Midnight Records RHM2 7904, 2004, compact disc.

${ }^{8}$ George Lipsitz, Footsteps in the Dark: The Hidden Histories of Popular Music (Minneapolis: University of Minnesota Press, 2007), xv.

${ }^{9}$ Richard Jackson Harris, A Cognitive Psychology of Mass Communication, 5th ed. (New York: Routledge, 2009$), 37$.
} 
Morrison, Ray Manzarek, Robby Krieger, and John Densmore, brought social and political philosophies to the band that fit into different niches of the broader cultural trends of the early- and mid-sixties. This paper will necessarily, perhaps unfortunately, focus more on the philosophy of Jim Morrison than the other members of the band. He defined the Doors for the majority of their audience, and the unique artistic perspective he brought to the band corresponded with many of the antecedents of the resistance movement that emerged in full bloom on radio and television in the summer of 1967. Listeners were aware of these ideas in the Doors' music and used them to categorize the band in ways that historians have not. The Doors and their promoters, meanwhile, continued to express their ideas through recordings, performances, interviews, and concert posters. Audiences and critics responded to these messages in diverse ways; while listeners and writers often did not draw a line between the Doors and hippie culture, the band attempted to separate themselves from the San Francisco scene and psychedelic "catch phrases." They wanted to express a more intellectual appeal. ${ }^{10}$

This fault between San Francisco and Los Angeles, perceived and articulated by the Doors, points toward the ongoing historical reinterpretation of the counterculture. Historians recognize that it was not a monolithic movement that attracted adherents with a universal set of messages and symbols, like peace and love, drugs and sex. The musical landscape of "the counterculture" was instead a multifaceted complex of different, overlapping subcultures, bound only by philosophies that challenged normative attitudes. Hippies were just one dominant subculture within the countercultural artistic milieu. The philosophies of these subcultures often coincided, but the people who participated in them demarcated the borders between their respective scenes when they felt it was necessary. The Doors represent another side of the resistance experience, a side fascinated with self-expression, darkness and release, sex and death. It was only after they were transformed by use into something new that these separate but overlapping subcultures were later compressed in popular memory into a single "hippie" experience. Historians can use the music and message of the Doors to illustrate the complexity of subcultures that made up the popular counterculture.

\section{Resistance Provenance}

In 1968, Rimbaud scholar Wallace Fowlie received a letter from Jim Morrison praising his latest book of translations of the brilliant, irreverent French poet's work. "Just wanted to say thanks for doing the Rimbaud translation," Morrison wrote. "I needed it because I don't read French that easily... I am a rock singer and your book travels around with me."11 Fowlie had no idea who Jim Morrison or the Doors were when he received the letter, but he later discovered that Morrison was especially fond of Rimbaud's "Oraison du Soir," or "Evening Prayer." The poem, in which Rimbaud describes sitting in a barber's chair, drinking "thirty or forty mugs" and smoking a pipe, while "A Thousand Dreams gently burn inside me," foreshadowed many of the characteristics that were already defining Morrison by $1968 .{ }^{12}$ Fans recognized that Morrison was wild and unpredictable; he was a rebel, just like Rimbaud. Many fans also recognized,

\footnotetext{
${ }^{10}$ The Velvet Underground approached their music with the same intellectual sensibilities. The darkly sensual "Venus in Furs" on their 1967 eponymous debut, for example, is based on the Leopold von Sacher-Masoch novel of the same title and explores themes of dominance and masochism.

${ }^{11}$ Wallace Fowlie, Rimbaud and Jim Morrison: The Rebel as Poet (Durham, NC: Duke University Press, 1994$), 15$.

${ }^{12}$ Arthur Rimbaud, Complete Works, Selected Letters, trans. Wallace Fowlie (Chicago: University of Chicago Press, 2005), 139.
} 
however, that Morrison's lyrics conveyed a sort of intellectualism that was missing from the pop charts prior to the Doors' debut album in 1967.

Rimbaud was just one of many hip intellectual influences that Morrison and the rest of the Doors brought to songwriting and performing. Antonin Artaud, Norman O. Brown, Herbert Marcuse, Friedrich Nietzsche, Sigmund Freud, Chicago blues performers like Howlin' Wolf, and the Maharishi Mahesh Yogi all inspired and informed the music, lyrics, and performances of the Doors. Many of these artistic and intellectual influences were influential within non-normative intellectual and artistic communities of the early- and mid-sixties. They possessed "revolutionary" credentials that contributed to the perceived countercultural relevance of the Doors.

Norman O. Brown's writing best conveys the foundations of countercultural thought as it was expressed by the Doors. In two works, Life Against Death in 1959 and an influential Harper's piece in 1961, Brown articulated a split between repressed, "Apollonian" society and a liberated, "Dionysian" self. "The Western consciousness has always asked for freedom," he wrote in Harper's, "but everywhere it is in chains; and now at the end of its tether." Liberation, in Brown's view, could come from "the blessed madness of the Maenad and the Bacchant." He advocated a search for "mysteries ... secret and occult." 13 Brown's work magnified upon and modified the analyses of modern society advanced by Herbert Marcuse, Friedrich Nietzsche, and Sigmund Freud. One of these, Herbert Marcuse, wrote of a potentially non-repressive society that was possible only by the liberation of happiness, which he identified with Eros-libido. "The sacrifice" of Eros "has paid off well," he insisted in the opening pages of his 1955 work Eros and Civilization. "In the technically advanced areas of civilization, the conquest of nature is practically complete, and more needs of a greater number of people are fulfilled than ever before." Unfortunately, though, "intensified progress seems to be bound up with intensified unfreedom." ${ }^{14}$ Mirroring Freud, Marcuse argued that "unfreedom" was caused by the repression of libido. But how, he asked, could society liberate itself and continue to enjoy the benefits of progress? Only through a unification of Apollonian discipline and Dionysian freedom, he argued, were happiness and progress simultaneously possible. Brown, on the other hand, argued that progress was only possible through the revelation of "some mystery, some secret" and that there came a time when society "has to be renewed by the discovery of new mysteries." It was time, he argued, to discover these new secrets. ${ }^{15} \mathrm{He}$ affirmed an element of the Apollonian in Life Against Death, though, when he maintained that Eros_ "the life instinct" - could only "magnify life" by assisting the "death instinct." 16

Jim Morrison was well-versed in these philosophies but took a middle ground between Brown and Marcuse. He was excited by Nietzsche's Birth of Tragedy, in which the philosopher argues that the Greek drama is successful because it embeds the Dionysian, in the form of the chorus, within the Apollonian, expressed through the narrative itself and its catastrophic conclusion. A 1968 interviewer reported that Morrison "suggests you read Nietzsche on the nature of tragedy to understand where he is really at" but missed the larger point somewhat when he asserted that "there was no need to guess which side" of the "Apollonian-Dionysian struggle for control of the life force" Morrison identified with. His performances with the Doors expressed both aspects of the struggle: sex and pleasure, Dionysus; and death and logic,

\footnotetext{
${ }^{13}$ Norman O. Brown, “Apocalypse: The Place of Mystery in the Life of the Mind,” Harper's, May 1961, 47-49. http://harpers.org/archive/1961/05/apocalypse/.

${ }^{14}$ Herbert Marcuse, Eros and Civilization (Boston: Beacon Press, 1974), 3-4.

${ }^{15}$ Brown, "Apocalypse," 48.

${ }^{16}$ Norman O. Brown, Life Against Death: The Psychoanalytical Meaning of History, 2nd ed. (Middletown, CT: Wesleyan University Press, 1985), 109.
} 
Apollo. As a performer, nonetheless, he was eager to apply the philosophies of Nietzsche, Marcuse, and Brown to the theater. When he was a student at Florida State University in the early sixties, Morrison was deeply engaged with a class on the philosophies of protest. A student recalled for a 1981 biography that Morrison "could draw the professor into amazing discussions ... and the rest of us would sit there dumbfounded." ${ }^{17}$ He was intrigued by Freudian sexual neuroses and developed a theory of the psychology of crowds that he tested at the university. "I can just look at [a crowd]," he told some other students, "and I can diagnose the crowd psychologically." Four students performing together, he said, could "cure" the crowd's neuroses. "We can make love to it. We can make it riot." 18 For Morrison, art offered the best chance to put his ideas to work. He transferred to UCLA in 1964 to pursue a degree in cinema before forming the Doors and enacting the Dionysian-Apollonian struggle on stage.

The Dionysian spirit of abandon and freedom found resonance in the emerging counterculture. One scholar observes that, by the end of the 1960s, using the term "Dionysian" to describe some new cultural development "was to risk cliché." Saul Bellow's main character in the novel Herzog observed an "erotic renaissance," or "Dionysian Revival" as early as $1964 .{ }^{19}$ According to Norman Brown, this "revival" was open to all comers. In Life Against Death, he insisted that the Dionysian consciousness "does not observe the limit, but overflows; [It is] consciousness which does not negate any more." 20 These ideas held a mass appeal that became evident in the "revolutions" of 1967. One contemporary, historian Theodore Roszak, observed in 1969 an "unprecedented penchant for the occult, for magic, and for ritual," which played an important part in the protest movements of the late sixties. As an example, he cites an October, 1967 demonstration in which fifty thousand protesters marched on the Pentagon. One group of these marchers "'cast mighty words of white light against the demon-controlled structure,' in hopes of levitating that grim ziggurat right off the ground." 21 A bright orange button promoting the event depicted a pentagon floating over a field of grass. It read: "The Pentagon is Rising October 21."22 Even if antiwar activists did not believe that the power of the occult could actually levitate the Pentagon, they believed that the mysterious language and imagery associated with it could inspire their movement.

The occult influenced other aspects of the band's public image. A November 1967 article in the New York Times reported that guitarist Robby Krieger and drummer John Densmore were "disciples of the Indian mystic Maharishi Mahesh Yogi." ${ }^{23}$ In 1966, organist Ray Manzarek met Krieger and Densmore in a meditation class at "one of the first meditation centers of the Maharishi," according to 1968 interview in Eye magazine. ${ }^{24}$ The Maharishi's impact on sixties pop culture was almost the brunt of satire by the end of the decade. A 1971 New York Times article on the popularity of meditation opened, "The Maharishi Mahesh Yogi, remember?"25 Manzarek, Krieger, and Densmore were involved with Transcendental

\footnotetext{
${ }^{17}$ Jerry Hopkins and Danny Sugerman, No One Here Gets Out Alive (New York: Grand Central, 1980), 31.

${ }^{18}$ Ibid., 32.

${ }^{19}$ John Carlevale, "The Dionysian Revival in American Fiction of the Sixties," International Journal of the Classical

Tradition 12, no. 3 (2006): 364.

${ }^{20}$ Brown, Life Against Death, 308.

${ }^{21}$ Theodore Roszak, The Making of a Counter Culture; Reflections on the Technocratic Society and Its Youthful Opposition (Garden City, NY: Doubleday, 1969), 124-25.

22 Jo Freeman, "Levitate the Pentagon (1967)," Jo Freeman.com, accessed November 29, 2012, http://www.jofreeman.com/photos/Pentagon67.html.

${ }^{23}$ Alfred G. Aronowitz, “The Doors Seek Nirvana Vote Here,” New York Times, November 25, 1967.

${ }^{24}$ Digby Diehl, "Love and the Demonic Psyche," Eye, April 1968, reproduced at "Eye: The Doors Story," accessed November 18, 2012, http://www.angelfire.com/id/doorslover/eye.html.

${ }^{25}$ Michael T. Kaufman, “Teacher is Gone, but Meditators Multiply,” New York Times, January 11, 1971.
} 
Meditation at least a year before the Beatles or Rolling Stones made the guru into a national figure in 1967, at a time when his spiritual philosophy was still underground.

These elements came together in performance. Under the influence of Antonin Artaud, Jim Morrison envisioned theatrical musical performances that went beyond Freud's sexual neuroses of the crowd or Nietzsche's Apollonian and Dionysian analysis of tragedy. The French dramatist and poet Artaud advocated a "theater of cruelty" that would cut through a viewer's "false reality" by depicting unflinching scenes of emotional and physical violence. In his 1938 manifesto he wrote, "we need above all a theater that wakes us up: nerves and heart." 26 The idea that theater could "find itself ... by furnishing the spectator with the truthful precipitates of dreams" ${ }^{27}$ excited stage performers, directors, and writers throughout the sixties. A January 1964 arts report in the Christian Science Monitor, for example, reported on a "curious and interesting innovation" being attempted by the Royal Shakespeare Company, who were "giving a sort of surrealist program based on the theatrical theories of the Frenchman, Antoine Artaud [sic]." ${ }^{28}$ These ideas were linked to politics. The dean of the School of Drama at Yale wondered in a 1968 editorial whether the "New Theater," drawing from "a great number of avant-garde influences," Artaud included, was linked with the "New Politics." ${ }^{29}$ With its unique mixture of both Dionysian stagecraft and the Theater of Cruelty, the play Dionysus in '69 troubled the Time magazine reviewer sent to report on it. "Sweaty, tangled heaps of men and women" engaged in an "orgy" on stage, the reviewer wrote, clucking that "playgoers may wonder whether Dionysus was the Greek god of wine or voyeurism." Artaud's ideas were "behind all this," according to Time, but it was "shamelessly alive from the waist down and shamefully dead from the neck up." 30

The "sex and death" dialectic at the center of the Doors' music, then, was situated in a dramatic milieu that was already experimenting with Artaud and Dionysus on the same stage. In a 2003 interview, Manzarek explained the theatrical philosophy championed by the band. "Each song," he told interviewer Harvey Kubernik, "had to have a dramatic structure.... You had to have dramatic peaks and valleys." 31 Morrison drew a direct connection between Greek tragedy and Doors performances in a 1967 interview with The Harvard Crimson. "We're right at that middle ground where it's not quite drama and it's not quite primitive either," he explained. Like the Greek theater, which started with just one actor on the stage, music was developing more advanced dramatic forms. "Maybe two actors will come next, then three, and then it'll be a drama instead of just a song." 32

The Doors engaged with a number of ideas that were popularly associated with the sixties counterculture. They brought together in their music and performances the liberating philosophy of Dionysian freedom, the intriguing and hip spirituality of Transcendental Meditation, and avant-garde theories from the radical fringes of theater. Listeners familiar with these ideas would have understood the "scene" credibility they bestowed upon the band. Sociologists and cultural studies scholars have identified

\footnotetext{
${ }^{26}$ Antonin Artaud, The Theater and Its Double, trans. Mary Caroline Richards (New York: Grove Press, 1958$), 84$.

${ }^{27}$ Ibid., 92.

${ }^{28}$ Harold Hobson, “The Arts and Other Things: A Glimpse Into Actors' Workshop,” Christian Science Monitor, January 29, 1964.

${ }^{29}$ Robert Brustein, "New theater, New Politics?," New York Times, August 25, 1968.

30 "New Plays: Dionysus in '69," Time, June 28, 1968, 83.

${ }^{31}$ Ray Manzarek, "Bloody Red Sun of Fantastic L.A.," in This is Rebel Music: The Harvey Kubernik InnerViews, ed. Harvey Kubernik (Albuquerque: University of New Mexico Press, 2003), 6.

${ }^{32}$ Jeffrey C. Alexander, "Psychedelic Revolution in Rock 'n' Roll: Confessions of Four Doors Who Made It," Harvard Crimson, October 13, 1967, http://www.thecrimson.com/article/1967/10/13/psychedelic-revolution-in-rock-n-roll/.
} 
the intimate connections between music and identity. ${ }^{33}$ The Doors would have affirmed the "countercultural" credentials of fans that identified with the same ideas. Through performances, interviews, and promotional materials between 1967 and 1971, they clarified and refined their own cultural credentials.

\section{Publicity, 1967-1971}

In their music and lyrics, the Doors called upon their underground ideological provenance to explore a variety of "countercultural" themes. At the same time, promoters and journalists created an image of the band that was at times "psychedelic," outrageous, revolutionary, or ridiculous, depending on their stance. Over the course of their career, the band's viewpoints on some of the key issues of the sixties evolved. An examination of their stance on these issues reveals some of the differences between the Doors (along with other Los Angeles bands) and their counterparts from San Francisco, who were also identified as part of the "movement." Some of these differences were intentionally emphasized by Morrison, Manzarek, Krieger, and Densmore to distance themselves from what they believed to be psychedelic "catch phrases" that simplified the music. Others were more apparent in the descriptions of their music and performances in the media. Drugs, sex, politics, and the rest of sixties culture came under their gaze in six studio albums and numerous live performances between 1966 and 1971.

The Doors were intimately associated with sexuality in the minds of their audience. A November 1967 article in the New York Times explained that "Jim Morrison considers the Doors as something more than a hit rock 'n' roll group," but his image was "directed at the same constituency as the Monkees: Those 14-year-old girls of America's suburbs.... [His] vision is packaged in sex." 34 There was some truth in this analysis. Rock journalist Harvey Kubernik recalls the early months of the Doors' popularity while he was in high school: "At first it didn't seem to matter that we boys listened to the Doors," he remembers, "[because] the girls in ... homeroom couldn't care less." After the band's appearance on the Ed Sullivan Show in September 1967, though, "it got to the point where we guys couldn't compete with Jim Morrison.... He was the ultimate beautiful bad boy." 35 This pattern continued to be a significant part of the band's appeal for the rest of their public career. Another New York Times article, from 1970, reported on a concert at Madison Square Garden. "Onstage assaults, where teen-age girls must be pried off the bodies of the performers," writer Mike Jahn opined, "are tributes usually reserved for the best-known rock idols." During the concert, "at least two dozen ... girls and quite a few boys" were removed from the stage. ${ }^{36}$ Fans expected a highly sexual performance and could be disappointed when a concert didn't meet their expectations. One fan expressed his or her frustration in a letter to the Chicago Tribune after a November, 1968 performance. "All I had heard about the Doors (Morrison in particular) was the fantastic stage show they provide," the writer fumed, but Morrison "stood listlessly thru the whole show and mumbled to himself and hardly moved at all." He jumped in the air during one song, but the anonymous

\footnotetext{
${ }^{33}$ See Storey, Cultural Studies, 102.

${ }^{34}$ Aronowitz, "The Doors Seek Nirvana Vote Here."

${ }^{35}$ Quoted in Chuck Crisafulli, The Doors: When the Music's Over: The Stories Behind Every Song (New York: Thunder' Mouth Press, 2000), 16-17.

${ }^{36}$ Mike Jahn, "The Doors Draw Active Audience: Rock Group's Singer Has to Be Saved from Fans," New York Times, January 19, 1970.
} 
correspondent was unimpressed: "his shirt flew up, and we saw his tummy. Wow." ${ }^{\text {"7 }}$ According to most reports, this fan's experience was rare.

This type of sexual appeal was not too different from other popular music acts. Morrison appeared in teenage magazines like Tiger Beat and was a locker pinup for girls at Harvey Kubernik's high school. Morrison articulated a particular brand of political sexuality, however, that countercultural audiences would have recognized as something more than Tiger Beat fodder. "Maybe you could call us erotic politicians... [There is] politics, but our power is sexual," he told a Times reporter in 1969. He believed that, at a Doors performance, sexuality "starts with just me" before including the "charmed circle of musicians on stage." After that, it "goes out to the audience" through the music and "interacts with them." After they took it home and "[interacted] with the rest of reality," Morrison would "get it back by interacting with that reality." ${ }^{38}$ As with "New Theater" and "New Politics," commentators were interested in the "New Morality." In a 1970 CBC radio interview, Morrison elaborated on it. "When I was in high school, and even college, which wasn't that long ago," he told interviewer Tony Thomas, "sex was still in the Victorian age. It was very hush-hush.” By 1970, though, "this new group of kids that's coming along ... [is] much more free." Linking their sexuality with politics, Morrison claimed that the new developments were "completely beneficial," as "the repression of sexual energy has always been the grandest tool of a totalitarian system." 39 Many young people across the country were engaged in the same types of conversations about sex. Historian Beth Bailey discusses the New Morality at the University of Kansas in Sex in the Heartland. "For some, sex itself became a moral claim," she writes, "a way of distancing oneself from mainstream or "straight' society." Morrison labored to inject himself, his poetry, and his band into this discussion.

Authority figures certainly linked the Doors with the potentially dangerous New Morality. At a New Haven concert, the show was stopped and Morrison was arrested after announcing to the audience during a song that a police officer had interrupted him and a girl backstage and sprayed mace in his eyes. Morrison viewed the incident as an example of police brutality and attempted to bring the audience to his side. "I want to tell you about something that happened just two minutes ago right here in New Haven," he told the audience from the stage, "this is New Haven, isn't it, New Haven, Connecticut, United States of America?" He told the audience about meeting a woman backstage and finding a shower room for some privacy. "We weren't doing anything, you know," he continued, keeping time with Densmore's drum rhythm, "just standing there and talking," until a "little man, in a little blue suit, and a little blue cap" came in and maced him. ${ }^{41}$ The audience took Morrison's side, and the arena erupted in violence after Morrison was arrested. ${ }^{42}$ The police press release, meanwhile, claimed that the show was "an indecent and immoral exhibition." ${ }^{43}$

Two years later, Morrison faced charges for exposing himself to an audience in Miami, Florida. While band members claimed that Morrison only simulated exposing himself to the audience, newspapers

\footnotetext{
${ }^{37}$ Robb Baker, "The Sound: Music and Radio: For Young Listeners," Chicago Tribune, November 7, 1968, section B.

${ }^{38}$ Michael Lydon, “The Doors: Can They Still 'Light My Fire'?,” New York Times, January 19, 1969.

${ }^{39}$ Jim Morrison, interviewed by Tony Thomas, The Lost Interview Tapes Featuring Jim Morrison, vol. 1, The Doors, Rhino/Bright Midnight Records RHM2 7904, 2004, compact disc.

${ }^{40}$ Beth Bailey, Sex in the Heartland (Cambridge, Mass: Harvard University Press, 2002), 155.

${ }^{41}$ Powledge, "Wicked Go The Doors," 92-93.

${ }^{42}$ Morrison referred to the incident in "Peace Frog" on the 1970 release Morrison Hotel, singing of "blood on the streets of New Haven."

43 “New Haven Police Close 'The Doors': Use of Mace Reported,” New York Times, December 11, 1967.
} 
reported the official version of events. ${ }^{44}$ The incident brought out the "Legion of Decency" according to a Washington Post journalist, who attempted to "wipe Morrison off the musical map." 45 FBI records released under the Freedom of Information Act reveal the outrage that Morrison and other rock acts inspired in one citizen. He authored a letter to Senator Sam Ervin and FBI Director J. Edgar Hoover in March 1969, enclosing an album by the Fugs and a press clipping on the Miami incident. "I don't know what, if anything, can be done to stop the distribution of such trash," he wrote. "I think the time is long past due when the great mass of decent Americans can be assured that such as this will not be allowed to be peddled to their kids" in record stores. Hoover sent him a letter back, assuring him of his personal concern. "It is repulsive to right-thinking people," he told him, "and can have serious effects on our young

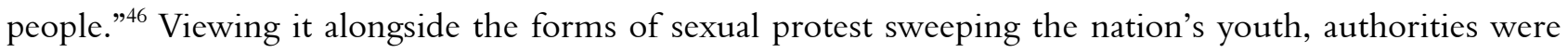
troubled by the sexuality of the Doors but powerless to do anything about it. Morrison was only convicted of two misdemeanors in the wake of the Miami incident.

Drugs and politics rounded out the Doors' radical message, but also illustrated the ways that the band tried to distance itself from the rest of the popular counterculture. Drugs were an important part of the band's mystique from the beginning. Manzarek recalled their 1966 vision of the band in a 2003 interview: "[we were] going to be strange and eerie and LSD-infused." ${ }^{47}$ Rumors of their early excesses at the Whisky a Go Go in 1966 were legendary. "Ray sniffed an amyl nitrate cap" before a show, a 1968 article in Eye reported, "and played so long he had to be dragged away from the organ." Morrison, during the same period, "was so consistently high on acid ... that he could eat sugar cubes like candy without visible effect." ${ }^{48}$ Concert promoters were anxious to pitch the Doors as a psychedelic act. One concert poster from an April 1967 show at the Avalon Ballroom in San Francisco featured the Doors and their opening acts in almost unreadable type underneath a swirling, red and blue vortex superimposed over the image of a naked woman. ${ }^{49}$ East Coast promoters used the same appeal. A poster from an October 1967 show at The Surf in Nantasket, Massachusetts, looked like an oil projector depicting a woman with long, flowing hair. The details of the concert were, again, almost unreadable. ${ }^{50}$ These posters followed a recognizable form than fans could use to categorize the band. ${ }^{51}$

On the national stage, the Doors attempted to distance themselves from the overt psychedelic culture. They made their views clear in an October 1967 interview in the Harvard Crimson. When the interviewer claimed that the band "started" psychedelic music, they were dismayed. "They really throw that word around," Densmore replied, and Manzarek clarified: "That's become the catch phrase for the last half of the 1960's." Morrison wondered, "what could that possibly mean, you know? Psychedelic. What could that mean anyway?" Attempting to pin them down, the interviewer asked whether drugs were an important part of their creative process. They all rejected the idea, advocating a more general form of personal freedom instead.

\footnotetext{
${ }^{44}$ It is not entirely clear what happened in Miami.

${ }^{45}$ Richard Cowan, "Changing the Direction of Rock," The Washington Post, Times Herald, July 31, 1969, section C.

${ }^{46}$ Federal Bureau of Investigation, "The Doors," FBI Records: The Vault, accessed November 3, 2012, http://vault.fbi.gov/The\%20Doors.

${ }^{47}$ Manzarek, "Bloody Red Sun of Fantastic L.A.," 12.

${ }^{48}$ Diehl, "Love and the Demonic Psyche."

49 “THE DOORS - MILLER BLUES BAND - HAJI BABA,” Postergeist.com, accessed February 16, 2013, http://www.postergeist.com/posters/scans3/FD57.jpg.

${ }^{50}$ Douglas W. Burns, “Concert Poster: The Doors,” DWB \& Company, accessed February 16, 2013, http://dwbcompany.com/images/Doors_posterls.jpg.

${ }^{51}$ See Kevin M. Moist, "Visualizing Postmodernity: 1960s Rock Concert Posters and Contemporary American Culture," The Journal of Popular Culture 43, no. 6 (2010), 1245-46.
} 
Morrison: About drugs or anything else, I think everybody should do what they want, that's all.

Manzarek: Whatever the individual needs to do to get those inner feelings out is great. Drink, smoke, meditate, any one of a million things.

Morrison: Even celibacy.

Krieger: But we certainly don't need drugs to dull our senses. ${ }^{52}$

While this may have been a public relations response for a college newspaper, they assiduously avoided the "psychedelic" label in many other interviews. Morrison, especially, wanted to convey an intellectual image. In August, before the Crimson interview, they sat down with Mojo Navigator in San Francisco, which had a resident "experimenter" on the staff. Morrison quickly changed the subject during a lengthy monologue about a new drug, NDDN_-"one of Hoffman's drugs, the third step up from LSD 26." After the experimenter, "Cougar," explained his latest trip, Morrison replied, "Interviews are good, but ... critical essays are really where it's at." ${ }^{53}$ A year later he told Richard Goldstein of New York Magazine, "I wonder why people like to believe I'm high all the time. I guess ... maybe they think someone else can take their trip for them." ${ }^{54}$ Even so, Morrison was frequently under the influence of something, drugs or alcohol. Morrison's friend Digby Diehl recalled the singer's pre-show routine. He told an interviewer in 1998 that he would sit backstage with Morrison while he drank or smoked his way into character. "Often he'd arrive as the shy poet, and he would become that wild, theatrical sexual figure." ${ }^{55}$ Audience members threw joints onto the stage during performances, interviewers continued to ask Morrison and the Doors about drugs, and promoters continued pitching them as psychedelic acts. It is widely believed that Jim Morrison's death in 1971 was drug- or alcohol-related.

The most significant difference the Doors wanted their audience to be aware of was their disconnection from the San Francisco scene. They told as many people as possible that, musically and politically, they were not from Northern California and not part of the "love generation." While they used some of the same musical ideas to write their songs, the Doors were not influenced by folk-rock, and Jim Morrison's lyrics did not often encourage listeners to "feel good." Listeners were more likely to call them "evil" than look to them for peace and love. An album review in the Washington Post summarized the "recurring themes" in Morrison's lyrics: "[He has a] fascination with evil, the love-hate-sex equation, anarchy within a rigid social structure, a love of the surreal and macabre. ${ }^{, 56}$ Reporters and reviewers have used a rich vocabulary of dark adjectives to describe their sound. It was, at times, "satanic," "unsettling," "grotesque," "scary," or "dangerous." These descriptions affected the band's reception in particular segments of the counterculture. They were not invited to play any of the major festivals of the era. "They were afraid of us," Densmore recalled of the organizers of the 1967 Monterey Pop Festival in his 1990 autobiography. "We didn't represent the attitude of the festival: peace and love and flower power. We represented the shadow side." While his "flower-child half" really wanted to go to the festival, Densmore recalled, he was not able to attend because he was in "the demon Doors." 57

\footnotetext{
${ }^{52}$ Alexander, "Psychedelic Revolution in Rock 'n' Roll."

${ }^{53}$ Gregory Shaw, "Interview: With the Doors," Mojo Navigator 2, no. 2, (August 1967): 14-15, http://www.rockmine.com/Archive/Library/MojoNav/Mojol3.pdf.

${ }^{54}$ Richard Goldstein, “The Shaman as Superstar,” New York Magazine, August 5, 1968, 42.

${ }^{55}$ Holzman and Daws, Follow the Music, 202.

${ }^{56}$ Cowan, "Changing The Direction of Rock."

${ }^{57}$ John Densmore, Riders on the Storm: My Life With Jim Morrison and the Doors (New York: Delacorte Press, 1990), 11415 .
} 
Woodstock was a particularly thorny issue with Morrison. He drew a dark line between his artistic and political philosophy and the festival's philosophy in two 1970 interviews. "The hippie lifestyle is really a middle-class phenomenon," he told interviewer Tony Thomas in May, "and it could not exist in any other society except ours, where there's this incredible surfeit of goods, products, and leisure time." While preceding generations had struggled with depression and war, the sixties offered "money enough to live a kind of a flagrant, outrageous lifestyle. ${ }^{58} \mathrm{He}$ was even less equivocal in an October interview with ZigZag magazine interviewer John Tobler. "It seemed like a bunch of young parasites, being kind of spoon-fed this three or four days of ... well, you know what I mean." While he conceded that his statements were probably "sour grapes," he said that the audience at Woodstock was "not what they pretend to be, some free celebration of a young culture." Morrison further attacked their call for a "sudden, miraculous revolution," saying that it "would be unreal to me.... You have to be in a constant state of revolution, or you're dead." 59 The Doors' message was completely incompatible with Woodstock, according to Morrison, and hippies were bourgeois twits, at best.

The antipathy between the Doors and elements of the San Francisco scene went both ways. Manzarek remembers in his autobiography that "San Francisco didn't like L.A. Too plastic, not a real city." At their first show in the city, the audience was unenthusiastic: "Here was a band being featured as coming from L.A. And calling themselves The Doors? Well, how pretentious and how very plasticene. 'Boo, hiss!" "60 In a 1968 interview with British weekly Record Mirror, he said that "San Francisco likes to think of itself as a European culture apart from the rest of the U.S." Los Angeles was focused on business and industry while San Francisco was "trying to be creative." counterculture was, for some, deep and wide.

The Doors articulated a unique political vision that supported personal politics and mass resistance while remaining critical of the main currents of countercultural thought. The band's name signaled the foundation of Morrison's political ideas. Drawn from Aldous Huxley's The Doors of Perception (1954), Morrison explained that "The Doors are what's between the known and the unknown." 62 The "unknown" played a significant role for the band. In a 1970 interview, for example, Creem magazine correspondent Lizze James claimed that fans of the band saw Morrison as "a savior, the leader who'll set them all free." Morrison found the idea "absurd." "I think it's a lie," he told James, "everybody insists that freedom is what they want the most... But that's bullshit!" Instead, he argued, "people resist freedom because they're afraid of the unknown." The only way they could really be free, he argued, was to face "the greatest fear imaginable" - the unknown, in other words—in order to "be what you really are." Political revolution is impossible "until there's a personal revolution, on an individual level," Morrison maintained: "It's got to happen inside first." ${ }^{63}$ While Morrison rejected the type of radical political freedom associated with mass politics and the New Left, his focus on personal politics mirrored the consciousness-raising methods pioneered by second-wave feminism.

\footnotetext{
${ }^{58}$ Morrison, The Lost Interview Tapes.

${ }^{59}$ John Tobler, “The Doors," ZigZag, October, 1970, 8, http://mildequator.com/documents/magazines/ZigZag1970/zigzagpopup1.html.

${ }^{60}$ Ray Manzarek, Light My Fire: My Life With the Doors (New York: G.P. Putnam's Sons, 1998), 232.

${ }^{61}$ Lon Goddard, “Open The Doors,” Record Mirror, September 14, 1968, http://mildequator.com/interviews/html/longoddard.html.

${ }^{62}$ The Doors, interviewed by SUNY Oswego broadcasters, The Lost Interview Tapes Featuring Jim Morrison, vol. 1.

${ }^{63}$ Lizze James, "Jim Morrison: Ten Years Gone," Waiting for the Sun: the Spirit of Jim Morrison (archives), accessed November 18, 2012, http://archives.waiting-forthe-sun.net/Pages/Interviews/JimInterviews/TenYearsGone.html.
} 
The band took an unequivocal stance against the Vietnam War. The 1968 song "The Unknown Soldier" uses the war to address the core themes of fear and personal liberation. The song begins with a subdued tone; Morrison takes the role of a narrator oppressed by the conflict. "Wait until the war is over," he advises the listener, "and we're both a little older." This subdued tone gives way to a darkly surreal groove after an abrupt time change and Morrison narrates images of war broadcast on the news: "breakfast where the news is read," he sings, "television children fed / Bullet strikes the helmet's head." After the eponymous Unknown Soldier is "executed" in a dramatic martial interlude, the song repeats the subdued tone. "Make a grave for the unknown soldier / Nestled in your hollow shoulder," Morrison nearly whispers over the ethereal organ before repeating the chorus and taking the song out in a triumphant cacophony with cheering crowds and shouts of joy. The dramatic confrontation with fear and painindeed, the death of the "unknown" - in the song leads the listener to a climax of ecstatic release.

The band resisted war on several fronts. Youth formed the ideological center of their opposition from an early date. They took a stand against the militarization of children in a benefit show for the "No War Toys" organization in 1966, months before the release of their debut album. ${ }^{64}$ Morrison—the son of a Navy admiral-made his position clear in a 1970 interview on CBC radio. Young people were "the ones that always fight the wars," he told the interviewer: "they're the human fodder for the war machine. There just seems to be no way around it; there's just no cause." Touching on some of the themes in "The Unknown Soldier," Morrison explained that war on television was "a great drama, life and death right there, a struggle." The "glamour" of war "infected" Americans from youth, he explained: "with little kids running around playing war, playing cowboys and Indians or whatever ... somehow it's just ingrained in you from the beginning that there's something heroic, proving yourself in the battle." Ultimately, Morrison believed, "you have to entertain these utopian concepts that life could work without all that struggle." 65

While the Doors took a stance against the Vietnam War and in favor of personal liberation, Morrison was critical of some of the more "revolutionary" modes of sixties political activism. "Tell All the People," for example, was the first Doors song published under an individual songwriting credit. Krieger's lyrics contained the lines "get your guns / the time has come / to follow me down." Morrison demurred. "I don't want people getting their guns and following me," he told Krieger. "I'm not leading a violent revolution or anything." He refused to put his name on the song. ${ }^{66}$ Morrison was often deeply ambivalent about politics, focused more on personal expression. In the 1967 Harvard Crimson interview, for example, he argued, "if you're into politics, then it's real for you. If you're not, then it doesn't really exist, you know?” Despite the band's clear antiwar message, Morrison applied the same philosophy to Vietnam: "The war doesn't exist except for the soldiers and people involved directly with the war. Like I don't believe there is a war." Producer Paul Rothchild explained his take on Morrison's stance in Life magazine. "A few years ago you had social protest," he argued, but "to the modern ear, that's become corny." Protest, he continued, was "self-defeating, because it just gets people mad. What is significant is social comment." Morrison's social

\footnotetext{
64 “The Doors Performance Database," The Doors Guide, accessed November 18, 2013, http://www.thedoorsguide.com/history/1966/19660423.html.

${ }^{65} \mathrm{Jim}$ Morrison, interviewed by Tony Thomas, The Lost Interview Tapes Featuring Jim Morrison, vol. 1.

${ }^{66}$ Peter Doggett, There's a Riot Going On: Revolutionaries, Rock Stars, and the Rise and Fall of the '60s (Edinburgh: Canongate, 2007), 230.

${ }^{67}$ Densmore replied to Jim incredulously. "Really?" he asked, before Manzarek abruptly redirected the interview to the band's upcoming album. Jeffrey C. Alexander, "Psychedelic Revolution in Rock 'n' Roll: Confessions of Four Doors Who Made It," Harvard Crimson, 1967. See note 31.
} 
commentary-when he asks "what have they done to the earth? What have they done to our fair sister?" in When the Music's Over, for example_- "doesn't draw conclusions, doesn't say what the solution is." ${ }^{8}$ Unlike the self-assured activists leading the counterculture from San Francisco and the nation's college campuses, Jim Morrison and the Doors charted a more equivocal political course.

\section{Conclusion}

In 2001 Barry "The Fish" Melton, one of the founding members of Country Joe \& The Fish, contributed an essay about the counterculture to Long Time Gone, an academic historical retrospective of the sixties. "The 1960s I want to remember," he reminisced, "will always be that relatively small group of people in the San Francisco Bay Area" music scene. "I want to remember my mixed feelings of fear and pride, and the incredible sense of community I felt when singing 'We Shall Overcome' locked arm-in-arm with others at a civil rights sit-in." ${ }^{69}$ The popular narrative of countercultural resistance is also focused on Melton's San Francisco ideal. "Ask anyone born after 1964" about the sixties, the writers of a 1994 article claim, "and you will likely hear about how everybody was a hippie, protested social injustice and the Vietnam War, practiced free love, and smoked Marijuana." ${ }^{\prime 70}$ A more recent article in the OAH Magazine of History about secondary history education reveals how this stereotype is being perpetuated. "Lessons where students make tie-dyes, paint protest signs, or listen to the enduringly popular music of Jimi Hendrix testify to [a] widespread belief that familiarity breeds knowledge." ${ }^{71}$ While historians recognize that the counterculture was far more complex than the popular narrative would have it, their analyses are incomplete. Popular culture cannot be removed from any discussion of the era, but many historians continue to write about music that reinforce a "peace and love," hippie-dominated narrative.

For several reasons, the Doors offer a more nuanced view of the counterculture that, in turn, can help historians write more nuanced accounts of sixties resistance. First, they were influenced by ideas that were influential across the movements that coalesced into the popular resistance front of the late sixties. Many listeners knew what these ideas were and identified the Doors with them. By association, these listeners would have associated the band with the wider counterculture. Second, the band articulated an unorthodox brand of countercultural resistance that affirmed or rejected different aspects of the culture as it was discussed at the time and as it would later be constructed in popular memory. They advocated "sex as a weapon," while eschewing "psychedelia" and rejecting the more overt elements of hippie culture, especially Woodstock, in favor of "darkness" and "constant revolution." Finally, the wild popularity of the band (one TV interviewer told the audience that "their first album sold more copies than "My Weekly Reader"” $)^{72}$ points to the wide appeal of their countercultural brand. These millions of listeners deposited personal meaning in the songs in their own ways; their individual meanings make up the "hidden histories" of popular music and the counterculture. ${ }^{73}$ These hidden histories are the fabric of the historian's craft.

\footnotetext{
${ }^{68}$ Powledge, "Wicked Go the Doors," 89-90.

${ }^{69}$ Barry Melton, "Everything Seemed Beautiful: A Life in the Counterculture," in Long Time Gone: Sixties America Then and Now, ed. Alexander Bloom (New York: Oxford University Press, 2001), 156.

${ }^{70}$ Kenneth J. Bindas and Kenneth J. Heineman, "Image is Everything?: Television and the Counterculture Message in the 1960s," Journal of Popular Film \& Television 22, no. 1 (1994), 35.

${ }^{71}$ Stephen S. Mucher and Carrie E. Chobanian, "The Challenges of Overcoming Pop Culture Images of the Sixties," OAH Magazine of History 20, no. 5 (2006), 40, http://www.jstor.org/stable/25162084.

${ }^{72}$ William C. Woods, “Morrison Raps," The Washington Post, Times Herald, April 13, 1970, section B.

${ }^{73}$ Lipsitz, Footsteps in the Dark, xv.
} 


\section{Bibliography}

Artaud, Antonin. The Theater and Its Double. Translated by Mary Caroline Richards. New York: Grove Press, 1958.

Bailey, Beth. Sex in the Heartland. Cambridge, MA: Harvard University Press, 2002.

Bindas, Kenneth J., and Kenneth J. Heineman. "Image is Everything?: Television and the Counterculture Message in the 1960s." Journal of Popular Film \& Television 22, no. 1 (1994): 22-37. http://dx.doi.org/10.1080/01956051.1994.9943663

Brown, Norman O. "Apocalypse: The Place of Mystery in the Life of the Mind.” Harper's, May 1961, 4749. http://harpers.org/archive/1961/05/apocalypse/

_ Life Against Death: The Psychoanalytical Meaning of History, 2nd ed. Middletown, CT: Wesleyan University Press, 1985.

Carlevale, John. "Dionysus Now: Dionysian Myth-History in the Sixties." Arion, Third Series 13, no. 2 (2005): 77-116. http://www.jstor.org/stable/29737263

- "The Dionysian Revival in American Fiction of the Sixties." International Journal of the Classical Tradition 12, no. 3 (2006): 364-91. http://dx.doi.org/10.1007/s12138-006-0003-1

Chalmers, David Mark. And the Crooked Places Made Straight: The Struggle for Social Change in the 1960s. Baltimore, MD: Johns Hopkins University Press, 1996.

Crisafulli, Chuck. The Doors: When the Music's Over: The Stories Behind Every Song. New York: Thunder's Mouth Press, 2000.

Densmore, John. Riders on the Storm: My Life With Jim Morrison and the Doors. New York: Delacorte Press, 1990.

Didion, Joan. The White Album. New York: Pocket Books, 1979.

Diehl, Digby. "Love and the Demonic Psyche." Eye, April, 1968. Reprinted at "Eye: The Doors Story," accessed November 18, 2012, http://www.angelfire.com/id/doorslover/eye.html

Federal Bureau of Investigation. "The Doors.” FBI Records: The Vault. Accessed November 3, 2012. http://vault.fbi.gov/The\%20Doors

Fowlie, Wallace. Rimbaud and Jim Morrison: The Rebel as Poet. Durham, NC: Duke University Press, 1994.

Goddard, Lon. “Open he Doors.” Record Mirror, September 14, 1968. http://mildequator.com/interviews/html/longoddard.html

Goldstein, Richard. “San Francisco Bray.” In “Takin' It to the Streets”: A Sixties Reader, edited by Alexander Bloom and Wini Breines, 294-96. New York: Oxford University Press, 1995.

Goldstein, Richard. “The Shaman as Superstar.” New York Magazine, August, 5, 1968, 42-45. http://books.google.com/

Freeman, Jo. "Levitate the Pentagon (1967)." Jo Freeman.com. Accessed November 29, 2012. http://www.jofreeman.com/photos/Pentagon67.html

Harris, Richard Jackson. A Cognitive Psychology of Mass Communication, 5th ed. New York: Routledge, 2009.

Hobson, Harold. “The Arts and Other Things: A Glimpse Into Actors' Workshop.” The Christian Science Monitor, January 29, 1964. 
Hodgson, Godfrey. "Rock Music and Revolution." In The 1960s, edited by William Dudley, 207-17. San Diego, Cal: Greenhaven Press, 2000.

Hopkins, Jerry and Danny Sugerman. No One Here Gets Out Alive: The Biography of Jim Morrison. New York: Grand Central, 2006.

Holzman, Jac, and Gavan Daws. Follow the Music: The Life and High Times of Elektra Records in the Great Years of American Pop. Santa Monica, CA: FirstMedia Books, 1998.

Lipsitz, George. Footsteps in the Dark: The Hidden Histories of Popular Music. Minneapolis: University of Minnesota Press, 2007.

Marcus, Greil. The Doors: A Lifetime of Listening to Five Mean Years. New York: PublicAffairs, 2011.

Marcuse, Herbert. Eros and Civilization. Boston: Beacon Press, 1974.

Manzarek, Ray. "Bloody Red Sun of Fantastic L.A." In This is Rebel Music: The Harvey Kubernik InnerViews, edited by Harvey Kubernik, 1-26. Albuquerque: University of New Mexico Press, 2003.

—. Light My Fire: My Life With the Doors. New York: G.P. Putnam's Sons, 1998.

Melton, Barry. "Everything Seemed Beautiful: A Life in the Counterculture." In Long Time Gone: Sixties America Then and Now, edited by Alexander Bloom, 145-58. New York: Oxford University Press, 2001.

Moist, Kevin M. "Visualizing Postmodernity: 1960s Rock Concert Posters and Contemporary American Culture." The Journal of Popular Culture 43, no. 6 (2010): 1242-65.

http://dx.doi.org/10.1111/j.1540-5931.2010.00798.x

Mucher, Stephen S., and Carrie E. Chobanian. "The Challenges of Overcoming Pop Culture Images of the Sixties." OAH Magazine of History 20, no. 5 (2006): 40-43.

http://www.jstor.org/stable/25162084

“New Plays: Dionysus in '69." Time, June 28, 1968, 83.

Perone, James E. Music of the Counterculture Era. Westport, CT: Greenwood Press, 2004.

Powledge, Fred. "Wicked Go The Doors." Life, April 12, 1968, 86-93.

Rimbaud, Arthur. Complete Works, Selected Letters. Translated by Wallace Fowlie. Chicago: University of Chicago Press, 2005.

Rocco, John, ed. The Doors Companion: Four Decades of Commentary. New York: Schirmer Books, 1997.

Roszak, Theodore. The Making of a Counter Culture: Reflections on the Technocratic Society and Its Youthful Opposition. Garden City, NY: Doubleday, 1969.

Shaw, Gregory. "Interview: With the Doors.” Mojo Navigator 2, no. 2 (1967): 11-15. http://www.rockmine.com/Archive/Library/MojoNav/Mojo13.pdf

Storey, John. Cultural Studies \& the Study of Popular Culture. Athens: University of Georgia Press, 1996.

Sugerman, Danny, ed. The Doors: The Complete Illustrated Lyrics. New York: Hyperion, 1991.

Sundling, Doug. The Doors: A Guide, 2nd ed. London: Sanctuary, 2003.

The Doors. The Lost Interview Tapes Featuring Jim Morrison. Vol. 1. The Doors, Rhino/Bright Midnight Records RHM2 7904, 2004, compact disc.

Tobler, John. “The Doors.” ZigZag no. 16 (1970): 5-8, 35. http://mildequator.com/documents/magazines/ZigZag1970/zigzagpopup1.html 